and withdrawal of $200 \mathrm{mg}$. of sodium amylobarbitone nightly.

The investigation was possible only because of the objectivity and generosity of Roche Products Ltd. and of Dr. M. Duffus, of their Department of Clinical Research. Mr. A. Jamieson, Mr. S. Lewis, Mr. J. Noble, and Sister E. Falconer and her staff at the Royal Edinburgh Hospital collaborated.

\section{REFERENCBS}

Belleville, R. E., and Fraser, H. F. (1957). F. Pharmacol. exp. Ther., $120,469$.

Berger, R. J., and Oswald, I. (1962). 7. ment. Sci., 108, 457.

Collier, H. O. J. (1965). Nature (Lond.), 205, 181.

Dement, W. (1960). Science, 131, 1705.

- and Kleitman, N. (1957). \%, exp. Psychol., 53, 339.

Bvans, J. I., and Oswald, I. (1965). Electroenceph. clin. Neurophysiol., In press.

Fraser, H. F., Isbell, H., Eisenman, A. J., Wikler, A., and Pescor, F. T. (1954). Arch. intern. Med., 94, 34
Jouvet, D., Vimont, P., Delorme, F., and Jouvet, M. (1964). C. R. Soc. Biol. (Paris), 158, 756.

Jouvet, M. (1965). In Sleep Mechanisms, edited by K. Akert, G. Bally, and J. P. Schadé. Elsevier, Amsterdam.

Kales, A. Hoedemaker, F. S., Jacobson, A., and Lichtenstein, E. L. (1964). Nature (Lond.), 204, 1337.

Kessel, W. I. N. (1965). Brit. med. f. In press.

Le Gassicke, J., Ashcroft, G. W., Eccleston, D., Evans, J. I., Oswald, I., and Ritson, E. B. (1965). Brit. F. Psychiat., 111, 357.

Miller, N. E. (1964). In Animal Behaviour and Drug Action, Ciba Symposium, edited by $\mathrm{H}$. Steinberg. Churchill, London.

Ministry of Health (1964). Recent N.H.S. Prescribing Trends. H.M.S.O., London.

Oswald, I., Berger, R. J., Jaramillo, R. A., Keddie, K. M. G., Olley, P. C., and Plunkett, G. B. (1963). Brit. F. Psychiat., 109, 66.

and Thacore, V. R. (1963). Brit. med. F., 2, 427.

Rechtschaffen, A., and Verdone, P. (1964). Perceptual and Motor Skills, 19, 974.

Rushton, R., and Steinberg, H. (1964). In Animal Behaviour and Drug Action Ciba Symposium, edited by $\mathrm{H}$ Steinberg. Churchill, Londan

Williams, H. L. Hammack, J. T., Daly, R. L., Dement, W. C., and Lubin, A. (1964). Electroenceph. clin. Neurophysiol., 16, 269.

Williams, R. L. Agnew, H. W., and Webb, W. B. (1964). Ibid., 17, 376.

Wulff, M. H. (1959). The Barbiturate Withdrawal Syndrome., Munksgaard, Copenhagen.

\title{
Variation of Bowel Habit in Two Population Samples
}

\author{
A. M. CONNELL,* M.B., M.R.C.P.ED. ; CLARE HILTON, $\dagger$ M.B., B.S., D.oBST.R.C.o.g.; \\ G. IRVINE, $\ddagger$ L.R.C.P., L.R.C.S.ED. ; J. E. LENNARD-JONES,§ M.D., M.R.C.P. ; J. J. MISIEWICZ,§ M.B., B.S., B.SC.
}

Brit. med. F., 1965, 2, 1095-1099

It is often assumed that a healthy person has one bowel action each day, and there have been suggestions that a daily habit is not only natural but necessary. Few definitive studies of bowel habit exist, and the limits of normality are undefined. It has been suggested that normal limits cannot be set (Parks, 1943), and one standard text appears to imply that anything from one bowel action every few weeks or months to 24 bowel actions a day can be regarded as normal (Keele and Neil, 1961). Some definition of normal bowel habit is important in studies of persons complaining of " diarrhoea" or " constipation" where it is necessary to distinguish clearly between normal and abnormal. The studies now reported were undertaken to define the range of bowel habit in normal persons seen at health inspections in a factory and in patients seen at a general medical practitioner's surgery. Our interest in this study lay not so much in minor variations within the normal range, say between seven and ten bowel actions a week, but in defining the outside limits of normality. The opportunity has also been taken to determine the subjects' opinions about their bowel habit and the extent of the laxative habit in these populations.

\section{Method of Inquiry and Definitions}

The interviews were conducted by doctors or by nursing sisters specially trained for this work. All the interviewers used' the following form:

\begin{tabular}{|c|c|c|}
\hline Country of origin & & Date \\
\hline $\begin{aligned} & \text { Have you had }- \text { Typhoid } \\
& \text { Dysentery } \\
& \text { Food-poisoning }\end{aligned}$ & $\begin{array}{l}\text { yes/no } \\
\text { yes/no } \\
\text { yes/no }\end{array}$ & \\
\hline How many bowel actions do you have? & /day & $\begin{array}{l}\text { loose } \\
\text { formed } \\
\text { hard }\end{array}$ \\
\hline \multicolumn{2}{|c|}{ Have you had any change in bowel habit in past year? } & yes/no \\
\hline Do you take salts or laxatives & yes/no & $\begin{array}{l}\text { lweek } \\
\text { /month }\end{array}$ \\
\hline $\begin{aligned} & \text { Do you regard yourself as - normal ? } \text { loose? } \\
& \text { constipated ? }\end{aligned}$ & & \\
\hline
\end{tabular}

It will be seen that, in addition to details of the number of bowel actions a day, the subjects were asked to state the consistency of the stool, the occurrence of any change in bowel habit in the previous year, any history of dysentery, and whether they considered themselves normal or not. Inquiries were also made into laxative habits.

The subjects were placed into six groups with respect to bowel habit: (1) those who had an action twice a week or less frequently ; (2) those who had an action three or four times a week ; (3) those who had an action five to seven times a week; (4) those who had an action more often than once a day but fewer than three times a day; (5) those who had an action three times a day ; (6) those who had more than three bowel actions daily.

Those who took laxatives were divided arbitrarily into those who took them more often than once a week and those who took them less frequently.

\section{Part I. Results in an Industrial Community}

\section{G. IRVINE, A. M. CONNELL, J. E. LENNARD-JONES, J. J. MISIEWICZ}

The subjects studied were drawn from all sections of the population of three factories typical of many in the greater London area. In all, 1,055 persons were interviewed, comprising 655 women and 400 men. The age and sex distribution is shown in Table I. As is inevitable from a study of an

* Lecturer in Clinical Science, Royal Victoria Hospital, Belfast ; late Member of Scientific Staff'Medical Research Council, Gastroenterology Research Unit, Central Middlesex Hospital, London.

t Late Assistant in General Practice.

¥ Company Medical Adviser, T. Wall and Sons (Meat and Handy Foods) Ltd., London.

$\$$ Member of Scientific Staff Medical Research Council, Gastroenterology Research Unit, Central Middlesex Hospital, London. 
industrial community, no information has been obtained from persons at the extremes of life; and in this population there was also a predominance of females. None of the subjects was seeking medical advice. About three-quarters of them were seen in the course of the routine medical screening required of persons seeking employment in these factories making food products. The others were a random sample of persons recently employed and specially interviewed for the purpose of this study.

TABLE I.-Age and Sex Distribution of Sample from the Industrial Community

\begin{tabular}{cc|c|c|c|c|c|c|c} 
& & \multicolumn{9}{|c|}{ Age-groups } & Total \\
\cline { 3 - 5 } & $10-19$ & $20-29$ & $30-39$ & $40-49$ & $50-59$ & $60-69$ & \\
\hline Male &. & 88 & 173 & 50 & 47 & 33 & 9 & 400 \\
\hline Female &. & 117 & 231 & 86 & 127 & 89 & 5 & 655 \\
\hline Total &. & 205 & 404 & 136 & 174 & 122 & 14 & 1,055 \\
\hline
\end{tabular}

\section{Findings}

Bowel Frequency.-Table II presents the bowel habits of the subjects, and these results are illustrated in Fig. 1. Each figure is a percentage of the subjects in each age-group. The row totals show that only $0.6 \%$ of the population had actions on two occasions a week or less frequently, and $0.1 \%$ of the population had more than three bowel actions daily; $99.3 \%$ of the population fell within these limits. Table III presents details of the eight subjects with the greatest and least bowel frequency. The one subject who had more than three bowel actions daily had noticed a change in habit in the previous year, so it is possible that he had recently developed some gastro-

\begin{tabular}{|c|c|c|c|c|c|c|c|}
\hline \multirow{2}{*}{$\begin{array}{c}\text { Bowel } \\
\text { Actions }\end{array}$} & \multicolumn{6}{|c|}{ Age-groups } & \multirow{2}{*}{ Total } \\
\hline & $10-19$ & $20-29$ & $30-39$ & $40-49$ & $50-59$ & $60-69$ & \\
\hline $\begin{array}{ll}<2 / \text { weeks } & . . \\
3-4 / \text { week } & . . \\
5-7 / \text { "y } & . \\
>1-<3 / \text { day } \\
\text { 3/day } \quad . . \\
>3 / \text { day } \quad . .\end{array}$ & $\begin{array}{r}0.0 \\
2.9 \\
71 \cdot 7 \\
23.9 \\
1.5 \\
0\end{array}$ & $\begin{array}{r}1.0 \\
3.0 \\
70.5 \\
24 \cdot 8 \\
0.4 \\
0.3\end{array}$ & $\begin{array}{r}0.0 \\
3.7 \\
79 \cdot 4 \\
16.9 \\
0.0 \\
0\end{array}$ & $\begin{array}{c}0.6 \\
7.5 \\
60.9 \\
30.4 \\
0.6 \\
0\end{array}$ & $\begin{array}{c}1.6 \\
9.8 \\
53.3 \\
33.6 \\
1.6 \\
0\end{array}$ & $\begin{array}{c}0 \\
0 \\
42 \cdot 9 \\
57 \cdot 1 \\
0 \\
0\end{array}$ & $\begin{array}{r}0 \cdot 6 \\
4 \cdot 5 \\
68 \cdot 0 \\
26 \cdot 0 \\
0 \cdot 8 \\
0 \cdot 1\end{array}$ \\
\hline
\end{tabular}
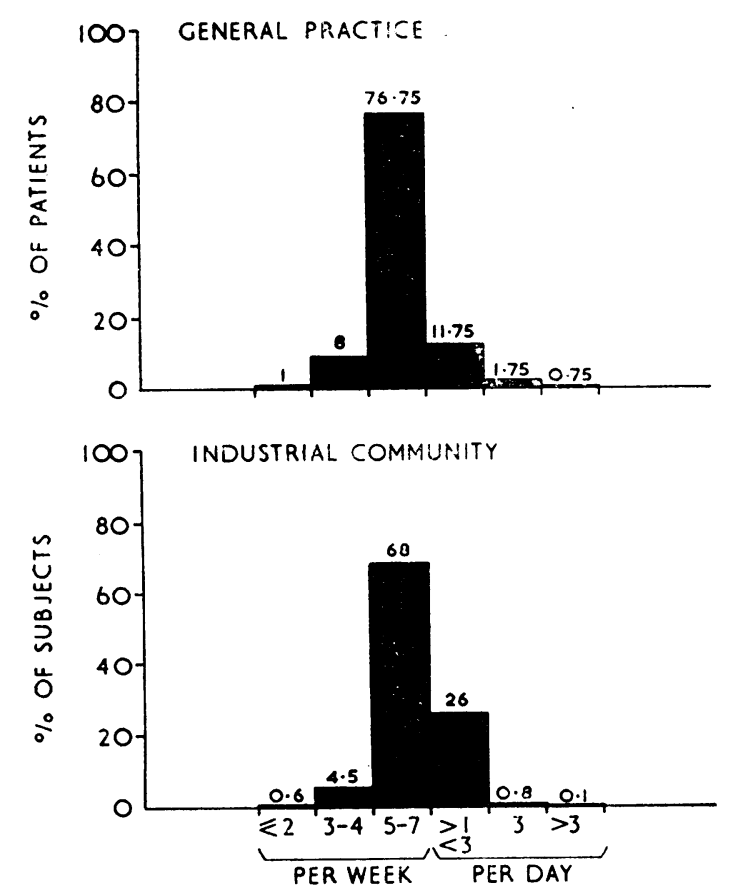

FIG. 1.-Proportion of subjects with different frequencies of bowel action. (Two population samples.) intestinal disorder. Of the subjects with infrequent bowel action one person had a bowel action on only one occasion each week, presumably in response to the weekly laxative. All these subjects were women and all but one thought that they were constipated.

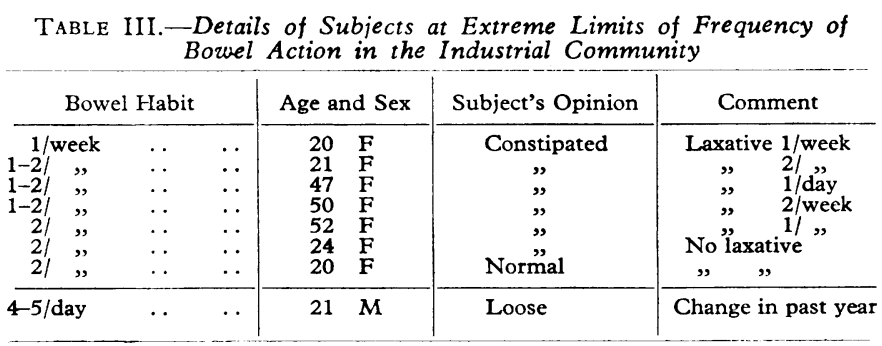

Bowel habit, Consistency of Stool, and Patient's Opinion.The majority of persons considered themselves to be normal. In the whole series, 43 persons (4\%) thought they were constipated. Of these, 22 had fewer than five bowel actions a week. Of the remaining 21 five described their stool as hard, though the frequency of bowel action was normal. The other 16 subjects had a normal frequency of bowel action and consistency of stool. Table IV shows the relation between bowel frequency and stool consistency. The stool tended, as expected, to be more loose with increasing frequency.

TABLE IV.-Relation Between Stool Consistency and Bowel Frequency in the Industrial Population. (Data Were Not Available for All Subjects)

\begin{tabular}{|c|c|c|c|c|c|c|}
\hline \multirow{2}{*}{$\begin{array}{c}\text { Stool } \\
\text { Consis- } \\
\text { tency }\end{array}$} & \multicolumn{5}{|c|}{ Bowel Frequency } & \multirow[b]{2}{*}{ Total } \\
\hline & $₹ 2 /$ week & 3-4/week & 5-7/week & $\begin{array}{l}>1- \\
<3 / \text { day }\end{array}$ & $>3 /$ day & \\
\hline $\begin{array}{l}\text { Loose } . \\
\text { Formed } \\
\text { Hard } . .\end{array}$ & $\begin{array}{l}0 \\
1 \\
6\end{array}$ & $\begin{array}{r}0 \\
27 \\
16\end{array}$ & $\begin{array}{r}23 \\
638 \\
22\end{array}$ & $\begin{array}{r}23 \\
232 \\
9\end{array}$ & $\begin{array}{l}4 \\
6 \\
0\end{array}$ & $\begin{array}{r}50 \\
904 \\
53\end{array}$ \\
\hline
\end{tabular}

Effect of Age.-Table II and Fig. 2 present the effect of increasing age on bowel habit. There is a suggestion that there is an increased scatter, both towards increased and decreased frequency, in age-group 40-59, but the numbers in age-group 60-69 are too small for any firm conclusion to be drawn about the continuance of this trend into later life.

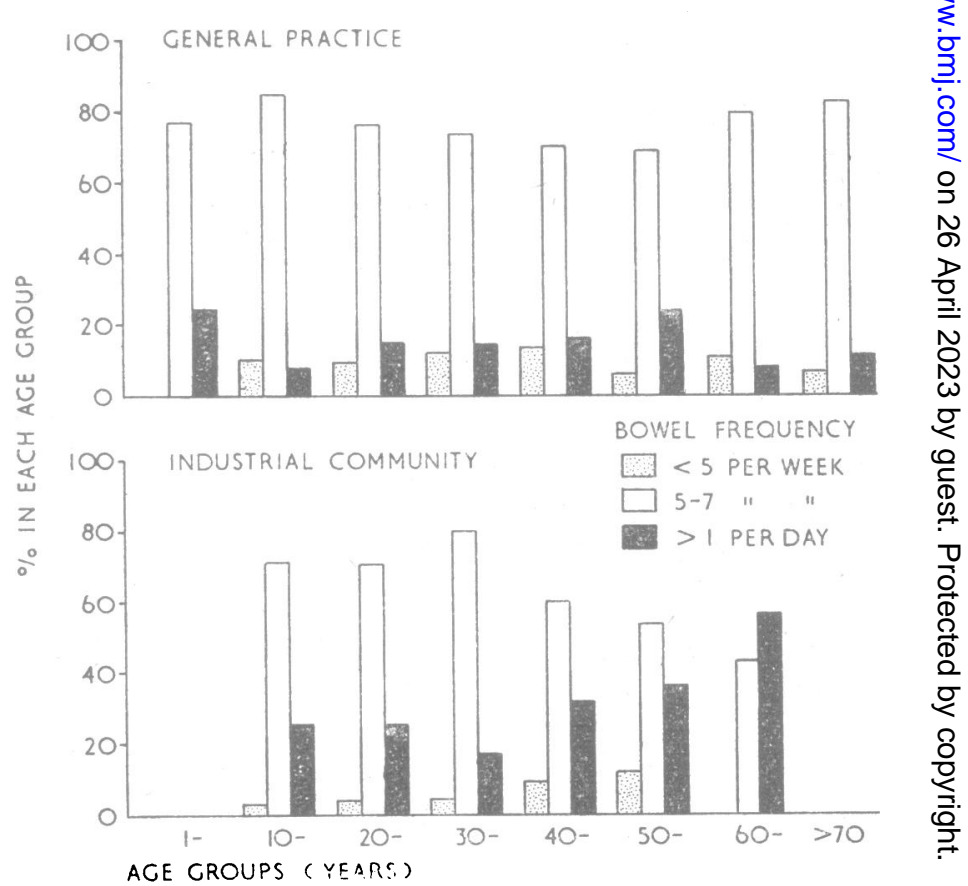

FIG. 2.-Correlation of age with bowel habit in two population samples. 
Effect of Sex.-There were no marked differences between the sexes except that a higher proportion of the females than males had fewer than five bowel actions a week. Thus $6.3 \%$ of the total female population, but only $3.5 \%$ of the male population, came into these categories. All the seven subjects with fewer than three bowel actions weekly were women.

Effect of Race.-There was no difference in bowel habit between 959 of the subjects from the United Kingdom and Eire and the remaining 96 persons who originated in other countries, mostly in the West Indies.

Laxative Habit.-A total of 170 persons, or $16.1 \%$ of the community, took laxatives: $34(3.2 \%)$ took them more often than once weekly, and $136(12.9 \%)$ took them less often. Table $\mathrm{V}$, showing how the laxative habit varies with age, indicates a great increase in regular laxative-taking with age. It is interesting that only $17 \%$ of the persons who took laxatives considered themselves to be constipated, $82 \%$ considered themselves normal, and $1 \%$ considered themselves loose. Table VI relates laxative-taking to the bowel habit. While, as would be expected, a high proportion of persons with infrequent bowel action took laxatives, there is no correlation between laxativetaking and the bowel habit of the occasional laxative users.

\begin{tabular}{|c|c|c|c|c|c|c|}
\hline \multirow{2}{*}{$\begin{array}{c}\text { Laxative } \\
\text { Takers }\end{array}$} & \multicolumn{6}{|c|}{ Age-groups } \\
\hline & $10-19$ & $20-29$ & $30-39$ & $40-49$ & $50-59$ & $60-69$ \\
\hline $\begin{array}{l}>1 / \text { week } \\
<1 / \text { week }\end{array}$ & $\begin{array}{l}0 \\
4 \cdot 4\end{array}$ & $\begin{array}{r}1 \cdot 7 \\
11.2\end{array}$ & $\begin{array}{r}1.5 \\
11.7\end{array}$ & $\begin{array}{r}5 \cdot 2 \\
23.6\end{array}$ & $\begin{array}{l}11 \cdot 5 \\
16.4\end{array}$ & $\begin{array}{l}14 \cdot 3 \\
35 \cdot 7\end{array}$ \\
\hline Total & $4 \cdot 4$ & 12.9 & $13 \cdot 2$ & $28 \cdot 7$ & $27 \cdot 9$ & 50 \\
\hline
\end{tabular}

TABLE VI.-Percentage of Subjects with Different Frequency of Bowel Action Who Took Laxatives More Often than Once a Week or Less Often in the Industrial Population

\begin{tabular}{c|c|c|c|c|c}
\hline \multirow{2}{*}{$\begin{array}{c}\text { Laxative } \\
\text { Frequency }\end{array}$} & \multicolumn{4}{|c}{ Bowel Frequency } \\
\cline { 2 - 5 } & $<2 /$ week & $3-4 /$ week & $5-7 /$ week & $>1-<3 /$ day & $>3 /$ day \\
\hline$>1 /$ week.. & 42.9 & 25 & 1.4 & 3.3 & 0 \\
$<1 /$ week & 14.3 & 20.8 & 11.0 & 16.8 & 0 \\
\hline
\end{tabular}

\section{Part II. Results in General Medical ? Practice}

\section{CLARE HILTON}

Method of Study.-The practice, situated in North-west London, served a population most of whom were in social groups III-V. So far as was possible, all patients entering the surgery during the period of study were interviewed. The only groups excluded were: (1) children under 1 year of age, (2) patients with known disease of the gastro-intestinal tract, and (3) patients taking drugs known to affect the bowel. The age and sex distribution of the 400 persons is shown in Table VII; it will be seen that, while females still predominated, the distribution of age was wider and more even than in the sample from the industrial community.

Table VII.-Age and Sex Distribution of the Subjects Seen in General Practice

\begin{tabular}{rr|c|c|c|c|c|c|c|c|c}
\hline \multirow{2}{*}{ Subjects } & \multicolumn{7}{c}{ Age-groups } & Total \\
\cline { 2 - 9 } & $1-9$ & $10-19$ & $20-29$ & $30-39$ & $40-49$ & $50-59$ & $60-69$ & $70+$ & \\
\hline Male & $\ldots$ & 9 & 20 & 10 & 16 & 19 & 26 & 18 & 16 & 134 \\
\hline Female & $\ldots$ & 8 & 24 & 37 & 38 & 40 & 42 & 45 & 32 & 266 \\
\hline Total &.. & 17 & 44 & 47 & 54 & 59 & 68 & 63 & 48 & 400 \\
\hline
\end{tabular}

\section{Findings}

Bowel Frequency.-Table VIII and Fig. 1 present the bowel habits of the subjects. Only $1 \%$ of the population had fewer than three bowel actions weekly, and $1 \%$ had actions more than three times a day; $98.25 \%$ of the population fell within these limits. Only three persons had more than three bowel actions daily; one was an epileptic boy of 10 years, one a woman of 39 with a chronic anxiety state, and one a grossly overweight woman of 60 . All three thought their stool to be loose. Four persons had fewer than three bowel actions weekly; all were women, and all regarded themselves as constipated.

TABLE VIII.-Effect of Age on Bowel Habit of Persons Attending a General Practitioner's Surgery. Figures are Percentages of the Total in Each Age-group

\begin{tabular}{|c|c|c|c|c|c|c|c|c|c|}
\hline \multirow{2}{*}{$\begin{array}{c}\text { Bowel } \\
\text { Actions }\end{array}$} & \multicolumn{8}{|c|}{ Age-groups } & \multirow{2}{*}{$\begin{array}{l}\text { Total } \\
(\%)\end{array}$} \\
\hline & $1-9$ & $10-19$ & $20-29$ & $30-39$ & $40-49$ & $50-59$ & $60-69$ & $70+$ & \\
\hline $\begin{array}{ll}2 / \text { week } & \ldots \\
3-4 / \text { week } & \ldots \\
5-7 / \text { week } & \cdots \\
>1<3 / \text { day } & \\
\text { 3/day } & \ldots \\
\text { > 3/day } & \text {.. }\end{array}$ & $\begin{array}{r}\overline{-} \\
76 \cdot 5 \\
17 \cdot 6 \\
5.9 \\
-\end{array}$ & $\begin{array}{r}\overline{9 \cdot 1} \\
84 \cdot 1 \\
4 \cdot 5 \\
\frac{2 \cdot 3}{2 \cdot 3}\end{array}$ & $\begin{array}{r}-\overline{8 \cdot 5} \\
76 \cdot 6 \\
12 \cdot 8 \\
2 \cdot 1 \\
-\end{array}$ & $\begin{array}{r}1.8 \\
9 \cdot 3 \\
74.1 \\
11.1 \\
1.8 \\
1.9\end{array}$ & $\begin{array}{c}1 \overline{13.6} \\
71 \cdot 2 \\
13.6 \\
1.6 \\
-\end{array}$ & $\begin{array}{r}2.9 \\
2.9 \\
70.6 \\
20.6 \\
2.9 \\
-\end{array}$ & $\begin{array}{r}1.6 \\
9.5 \\
80.9 \\
6.3 \\
1.6\end{array}$ & $\begin{array}{r}\overline{6.3} \\
83.3 \\
8.3 \\
2 \cdot 1\end{array}$ & $\begin{array}{c}1 \\
8 \\
76.75 \\
11.75 \\
1.75 \\
0.75\end{array}$ \\
\hline
\end{tabular}

Bowel Habit and Patient's Opinion.-Most people believed themselves normal. In the whole series $64(16 \%)$ considered themselves to be constipated. Of these, only 25 had fewer than five bowel actions per week.

Effect of Age.-Table VIII and Fig. 2 show the effect of increasing age on bowel habit. Between the ages of 10 and 59 there was a progressively decreasing proportion of persons with five to seven bowel actions weekly but no other obvious trend.

Effect of Sex.-There were no marked differences except that a higher proportion (6.8\%) of the females had fewer than five bowel actions a week, compared with $2.3 \%$ of the males. All four of the subjects who had fewer than three bowel actions weekly were women.

Effect of Race.-Too few foreign subjects were seen for separate analysis.

Laxative Habit.-A total of 117 persons (29.3\%) took laxatives. Of these, $58(14.5 \%)$ took them more than once weekly, the remainder less often. Table IX shows how the laxative habit varied with age ; there was a marked increase in frequency of laxative-taking with age. Of those who took laxatives $40.1 \%$ thought they were constipated.

TABle IX.-Percentage of Persons in Each Group Among Those Seen

\begin{tabular}{|c|c|c|c|c|c|c|c|c|c|}
\hline \multirow{2}{*}{\multicolumn{2}{|c|}{$\begin{array}{l}\text { Laxative } \\
\text { Takers }\end{array}$}} & \multicolumn{8}{|c|}{ Age-groups } \\
\hline & & $1-9$ & $10-19$ & $20-29$ & $30-39$ & $40-49$ & $50-59$ & $60-69$ & $70+$ \\
\hline $\begin{array}{l}>1 / \text { week } \\
\gtrless 1 / \text { week }\end{array}$ & $\ldots$ & $\begin{array}{l}0 \\
0\end{array}$ & $\begin{array}{l}0 \\
2 \cdot 3\end{array}$ & $\begin{array}{l}6 \cdot 4 \\
4 \cdot 2\end{array}$ & $\begin{array}{r}5 \cdot 6 \\
14 \cdot 8\end{array}$ & $\begin{array}{c}11.9 \\
15.3\end{array}$ & $\begin{array}{l}17 \cdot 6 \\
19 \cdot 1\end{array}$ & $\begin{array}{l}30 \cdot 2 \\
20 \cdot 6\end{array}$ & $\begin{array}{l}29 \cdot 2 \\
27 \cdot 1\end{array}$ \\
\hline Total & $\ldots$ & 0 & $2 \cdot 3$ & $10 \cdot 6$ & $20 \cdot 4$ & $27 \cdot 2$ & $36 \cdot 7$ & $50 \cdot 8$ & $56 \cdot 3$ \\
\hline
\end{tabular}

\section{Combined Series}

Of the 1,455 subjects, 1,441 ( $99 \%)$ had a bowel frequency within the range of three actions a week to three a day, inclusive ; only four had more than three bowel actions daily (and all were probably abnormal) and only two had one bowel action a week. Altogether, 287 persons (19.7\%) took laxatives, but only $92(6.3 \%)$ took them more often than once a week.

\section{Discussion}

In any investigation based on a questionary bias may be introduced both by the way in which the questions are asked 
and by the subjects' response. Sixteen nurses conducted the interviews in the factory and two doctors in the general practice. It is possible that different observers phrased the questions with different emphasis, but with 18 observers a systematic difference is unlikely. The response of the subjects in both surveys may have been influenced by a desire to conform to the generally accepted pattern. In the food factories a desire to conform may have been strengthened by the emphasis on hygiene implicit in the health check. 'The importance of these factors cannot be assessed but was probably small, because the findings in two different population samples were similar.

The most striking feature of the whole study was the narrow range of frequency of bowel habit in the two populations. Over the total series $99 \%$ (99.3\% in the factory population, $98.25 \%$ in the general practice population) of the subjects fell within the limits of having three or more bowel actions a week and no more than three bowel actions a day. These results support the view that a well-defined range of normality exists with respect to bowel habit.

Only two extensive surveys of bowel frequency seem to have been conducted previously. The best-documented is that of Parks (1943), who questioned 1,115 male postal employees in the lower-income groups who were seeking medical advice. $\mathrm{He}$ found that $6.3 \%$ of his subjects had less than one bowel action daily, $52.7 \%$ had their bowels open once daily, and $41.0 \%$ had them open more than once daily. Hardy's (1945) findings among 440 nurses were similar ; $9 \%$ of them had their bowels open less than once daily, $59 \%$ daily, and $32 \%$ more than once daily. The results of both these surveys differ little from those reported here, 20 years later under conditions of peace. In the industrial community $5.1 \%$ of the subjects had fewer than five bowel actions weekly, and $26.9 \%$ had more than one action daily. Among the patients attending the general practice surgery $9 \%$ had fewer than five bowel actions weekly, and $14.25 \%$ had more than one action daily.

There was no definite alteration of bowel frequency with advancing age. In the industrial population there was a suggestion that the distribution of bowel frequency tended to become broader in older age groups. Thus in older groups there was a higher percentage of persons with less frequent and also with more frequent bowel actions than at younger ages. Parks (1943) found that the frequency of bowel action remained approximately constant, except for a slight trend towards increased frequency in men aged 50-59. In the general practice survey there was perhaps a slight trend towards increased frequency in successive age-groups from 10 to 59 years, but this trend was not continued in the older age groups, who were not represented in the working population surveys. It can be argued that a real decrease in bowel frequency with age is not apparent, because of the increased use of laxatives by older people. This is possible, but seems unlikely because, as Parks (1943) has shown, laxatives are often taken for reasons unconnected with bowel frequency. In both the present series a higher proportion of women than men had fewer than five bowel actions weekly, and those who passed two or fewer stools weekly were all women.

The taking of laxatives tended to increase with age in both surveys. The overall difference in the proportion of subjects who took laxatives-16.1\% in the factory population and $29.3 \%$ in the general practice series-is accounted for by the increased proportion of older subjects in the latter. Thus, in the agegroup $10-59$ there were $15.5 \%$ of laxative-takers in the industrial community and $14.5 \%$ in the general practice population. However, at all ages there was a higher proportion of those who took laxatives more than once weekly among those attending the general practitioner's surgery than among those in industry. No subject among the 266 under the age of 20 took laxatives more than once weekly, and only three subjects in these age groups took any laxatives. None of the 17 children under 10 were being given laxatives.
It is interesting to compare these findings with previous data to see if the laxative habit of the population is changing. Park's findings in 1939 and 1940 were similar to our own in that the proportion of subjects who took laxatives rose steadily with increasing age, and this increase occurred almost entirely among those taking laxatives more than once weekly. However, his figures, which are compared with those of the present surveys in Table $\mathrm{X}$, suggest that the proportion of laxativetakers in the population is less to-day than it was 25 years ago. This suggestion that the laxative habit is decreasing is further supported by the fact that none of the children under 10 in the present survey were receiving laxatives, whereas in 1953 Reid (1956) found that $21.6 \%$ of children entering school at the age of 5 were being given laxatives at least once weekly.

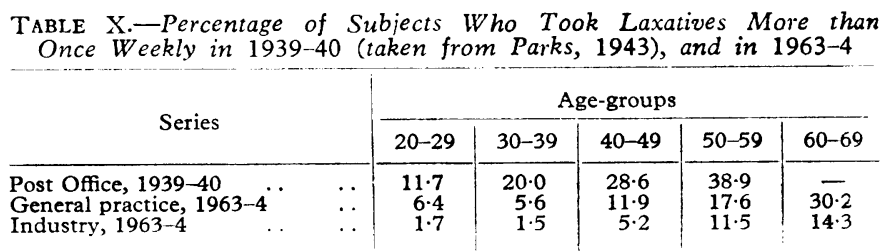

The results of the present questionary showed that, of those taking laxatives, $83 \%$ among the industrial population and $60 \%$ among the general practice patients did not regard themselves as constipated. It seems possible that these people take laxatives for reasons unrelated to the bowel habit, but no inquiry was made why the laxatives were being taken. Parks (1943). was able to establish the reason why many of his patients took them regularly. Only a small proportion took laxatives because they thought the stools insufficient in quantity or too hard; others took laxatives regularly for symptoms attributed to a disordered bowel reaction, on account of rheumatic pains, or because outside influences had persuaded them that they would benefit thereby.

One aim of these studies was to provide a basis for the definition of clinical abnormalities. The term "constipation" is unsatisfactory because it may be used to describe infrequent bowel actions, hard stools, or difficulty in defaecation. 'This study has been mainly concerned with bowel frequency, though it has also shown that the consistency of the stool is related to the bowel frequency. A bowel action fewer than three times weekly can be regarded as unusual. The term "diarrhoea" is also unsatisfactory, as it may be used to describe frequent bowel actions, loose stools, urgency of defaecation, or the passage of discharge with or without a normal stool. From the findings in these surveys the passage of three stools daily can be regarded as unusual, and more than three stools daily as probably abnormal.

\section{Summary}

Inquiries about bowel habit were made of 1,055 persons not seeking medical advice in an industrial community and of 400 patients, without known gastro-intestinal disease, attending a general medical practitioner's surgery.

Of the whole population $99 \%(99.3 \%$ in the industrial community and $98.25 \%$ in the general practice) fell within the frequency limits of three or more bowel actions weekly up to three actions daily. From these results it is suggested that fewer than three bowel actions weekly and more than three bowel actions daily may be regarded as unusual. Only two subjects in the combined series of 1,455 persons had one bowel action a week. Four subjects had more than three bowel actions daily, and in each case there is reason to believe that this frequency was abnormal.

All 11 subjects in the combined series who had fewer than three bowel actions weekly were women. In both series more women than men had fewer than five bowel actions weekly. 
No simple correlation between bowel habit and age was observed.

There was no correlation between bowel habit and nationality.

Four per cent. of the industrial population and $16 \%$ of those seen in general practice regarded themselves as "constipated." The use of this term sometimes correlated with infrequent bowel actions, and sometimes with hardness of the stool, but often it bore no relation to bowel frequency or stool consistency.

A correlation was observed between increasing bowel frequency and the subjects' opinion of the stool as "loose."

Of the total population $19.7 \%$ (16\% in the industrial community, $29 \%$ in general practice) took laxatives. The difference between the two series with regard to laxative-taking can be ascribed to different age distributions within the samples. The proportion of subjects who took laxatives increased with age in both series. No subject under 20 took laxatives more than once weekly, and only three of the 266 subjects in this age group took any laxatives. Only $20 \%$ of those who took laxatives in the combined series considered themselves "constipated."

We thank Lord Trenchard, chairman of T. Wall and Sons (Meat and Handy Foods) Ltd., for agreeing to the undertaking of this survey in the three factories, and the staff of the Company Medical Service who made it possible. We thank Dr. H. N. Levitt for his help and encouragement with the survey in general medical practice.

REFERENCES

Hardy, T. L. (1945). Lancet, 1, 519.

Keele, C. A., and Neil, E. (1961). Samson Wright's Applied Physiology, 10th ed., p. 392. Oxford University Press, London.

Parks, J. W. (1943). M.D. Thesis, Cambridge.

Reid, J. J. A. (1956). Brit. med. f., 2, 25.

\title{
Cytomegalovirus as a Possible Cause of a Disease Resembling Infectious Mononucleosis
}

\author{
E. KLEMOLA,* M.D. ; L. KÄÄRIÄINEN,* M.D.
}

Brit. med. F., 1965, 2, 1099-1102

So long as the aetiology of infectious mononucleosis is unknown, diagnosis will depend on the criteria set. There is a conflict of opinion on whether the presence of heterophilic antibodies against sheep erythrocytes in an abnormally high titre should be regarded as a criterion for diagnosis. The majority of clinicians to-day employ the diagnosis infectious mononucleosis even when the heterophil agglutination or the Paul-Bunnell test is negative, provided the clinical picture of the disease is compatible with infectious mononucleosis. However, many authors are of the opinion that the aetiology of Paul-Bunnellpositive and that of Paul-Bunnell-negative mononucleosis are different (Shubert et al., 1954 ; Hoagland, 1955 ; Hobson et al., 1958 ; Belfrage, 1962).

A significant rise in the titre of complement-fixing (C.F.) antibodies to the cytomegalovirus was demonstrated in the course of the disease in the serum of a man admitted to the Aurora Hospital in February 1965. His illness was regarded on clinical grounds as infectious mononucleosis, though the heterophil agglutination test was negative. On the basis of the interesting rise observed, a systematic study on the behaviour of the C.F. antibodies to the cytomegalovirus was initiated in patients with infectious mononucleosis and-as a control-in patients with various acute infectious diseases.

\section{Material and Methods}

The material consists of a series of 14 patients with a clinical diagnosis of infectious mononucleosis admitted to the hospital in February, March, and April 1965, whose titre of C.F. antibodies to the cytomegalovirus has been followed for a minimum of six weeks from the onset of the disease. The haematological criteria for the diagnosis were relative and absolute lymphocytosis and an abundance, not merely a transient appearance, of atypical lymphocytes. Five patients had a negative and nine a positive heterophil agglutination test. The clinical features

\footnotetext{
* From Aurora Hospital and from the Department of Virology, Univer-
} sity of Helsinki, Helsinki, Finland. of the former are discussed below; all the latter had tonsillitis and enlargement of the lymph nodes. The limit for positivity was set at a titre of 1:32 after guinea-pig-kidney absorption ad modum Dawidsohn. In addition, the C.F. test was performed on paired serum samples taken during the disease and stored at $-20^{\circ} \mathrm{C}$. from 10 patients who had been in the hospital in 1964 for Paul-Bunnell-positive mononucleosis. Antibodies were studied for an average of eight months after the onset of the disease in two of these cases found to have a high titre.

The control material consists of 308 patients of different ages with a history of various acute infectious diseases. From 130 of these patients at least two serum samples were taken at intervals of two to four weeks.

Cytomegalovirus, strain "AD 169," isolated by Rowe et al. (1956) from adenoid tissue, was kindly supplied in 1959 by Dr. W. P. Rowe, Bethesda, Md., to Dr. P. Halonen, at that time of this laboratory. The virus was passaged several times in human embryo fibroblasts. The identity of the passaged virus was established in 1962 by the co-operation of Dr. T. H. Weller, Harvard University, Boston ; Dr. Janet Hartley, Bethesda, Md. ; Dr. Gun Carlström, Department of Virus Research, Karolinska Institute, Stockholm; and Dr. P. Halonen, Department of Virology, University of Turku. The identification was made on the basis of typical cytopathic changes caused by the virus and of C.F. tests (Carlström, 1965).

In this study the cytomegalovirus was cultivated in human embryo skin muscle cells derived from embryos 8 to 16 weeks old. The maintenance medium was $92 \%$ Eagle's minimum essential medium, $3 \%$ horse serum, and $5 \%$ tryptose phosphate broth. Antigen for the C.F. test was harvested when the complete cytopathic effect had appeared. The culture was frozen and thawed three times successively, and the fluid was either centrifuged to remove the cell debris or used without prior centrifugation. The C.F. test was performed by a microtechnique with Microtiter equipment (Cooke Engineering Co., Alexandria, Virginia). Antigen was first titrated with known positive convalescent human serum obtained from Dr. 